\title{
SOCIAL MEDIA USE OF HOSPITALS IN TERMS OF COMMUNICATION AND PUBLIC RELATIONS
}

\author{
Ümmü Özlem ÇERÇİ \\ Lecturer (Phd Student), Selcuk University, Silifke-Tasucu Vocational School of Higher Education, \\ Mersin, Turkey \\ u.ozlemcerci@gmail.com
}

\begin{abstract}
After the widespread use of the Internet, which could be considered as the invention of the 21 st century, social media has begun to be used for public relations purposes, and even institutions, organizations and firms that are delayed in this period are criticized. When we look at the use of social media by sectors, the healthcare sector undoubtedly falls behind this movement. The purpose of this study is to investigate the use of social media by the hospitals with the aim of communication and public relations. The universe of this study is hospitals. Mayo Clinic, chosen as the best hospital of 2016 by U.S. News \& World Report, from the USA that is hometown of social media and Medical Park Hospital, taking the first place at the list of the best hospitals determined by Turkish Social Security Institution and at the same time being awarded the first prize in the field of healthcare by Golden Spider Web Prizes were determined as samples for this study. The websites of Mayo clinic and Medical park and their relevant social media tools such have been evaluated through qualitative and quantitative analysis method for a period of four weeks between 1st and 31st of December, 2016. It is one of the findings of this study in terms of these dynamics that health organizations centered in USA, which is named as the birthplace of social media as well, use social media more professionally and in relevantly.
\end{abstract}

Keywords: Social Media, Public Relations, Communication, Hospital

\section{HASTANELERIN HALKLA İLISSTKILER AMAÇLI SOSYAL MEDYA KULLANIMI}

\section{ÖZ}

21. yy'ın icadı sayılabilecek olan internetin yaygın kullanımından sonra sosyal medya da halkla ilişkiler amaçlı kullanılmaya başlanmış hatta bu mecrada yerini almakta geciken kurum, kuruluş ve firmalar eleştirilerle karşılaşmaktadır. Sosyal medyanın sektörler tarafından kullanımına baktığımızda en geriden gelenlerden biri de şüphesiz sağlık sektörüdür. Bu çalışmanın amacı sosyal medyanın hastaneler tarafından halkla ilişkiler amaçlı kullanımını araştırmaktır. Çalı̧̧manın evrenini hastaneler oluşturmaktadır. Sosyal medyanın doğduğu yer olması sebebiyle ABD'den, her sene USNews \& World Report Dergisi'nin yaptığı "En İyi Hastaneler" sıralamasında 1.sıradaki Mayo Clinic ve Türkiye'den SGK'nın 'En İyi Hastaneler' 2012 listesinde en çok şubeyle yer edinen aynı zamanda Altın Örümcek Web Ödüllerinde halk oylamasıyla sağlık kategorisinde 1.lik ödülü alan Medical Park Hastaneleri ise bu çalışmaya örneklem olarak seçilmiştir. Niteliksel ve niceliksel içerik analizi yöntemi ile Mayo Clinic ve Medical Park 'ın web siteleri, yer aldığı diğer sosyal medya araçları 01- 31 Aralık 2016 tarihleri arasında dört haftalık bir süre ile değerlendirmeye alınmıştır. Bu dinamikler çerçevesinde sosyal medyanın doğum yeri olarak da adlandırılan ABD merkezli sağlık işletmelerinin sosyal medyayı daha profesyonel ve amacına uygun olarak kullandığı bu araştırmanın sonuçları arasinda yer almaktadır.

Anahtar Kelimeler: Sosyal Medya, Halkla İlişkiler, İletişim, Hastaneler

\section{INTRODUCTION}

Today, internet and communication technologies are developing rapidly, and this development brings with it many changes in the field such as communication and public relations activities of organizations. The internet, which could be considered as the invention of the 21 st century, has 
become a medium via which acquired information and experiences are shared besides being used to get information. With the daily use of the internet, users firstly lived through the Web1.0 period where a content publisher and a content reader existed and then Web 1.0 gave place to Web 2.0. With Web 2.0, web sites visitors are not only consumers but also producers. Many people can communicate with each other simultaneously via Web 2.0 and many applications can be performed by social media tools defined in Web2.0 such as Twitter, Facebook, Google, Wikipedia (Güçdemir, 2012:29).

At its simplest definition, social media is the communication medium in which Web 2.0 technologies are used. Social media, also defined as Web 2.0 stations, communication tools, sites and online publications (Gunelius, 2011:10) that originate from discussions, connections and participations is the kind of media which people use to socialize (Safko, 2010:3). According to Kaplan and Haenlein(2009) social media is a set of web-based applications that are created on the technological and ideological infrastructure of Web 2.0 and allow for the creation and modification of user-based content. Social media, a form of media in which a number of new online information sources are created, identified and used by consumers with the intention of educating each other about products, brands, services, people and problems is a general definition of technology, social interaction, participation and content creation.

Contemporary public relations practices regard the two-way symmetric communication model as ideal model. Social media platforms are communication environments where organizations can interfere with individuals in their target groups; the flow of two-way communication is possible and is open to sharing and participation. Social media environments are the newest communication channels through which institutions can disseminate corporate communications messages in the context of public relations and can support application areas such as crisis management, event management, public opinion creation, and co-operation with stakeholders. The ability of social media channels to be measurable, traceable and its enabling to share and publish information quickly is an important communication channel feature in communicating with target audience in public relations (Onat, 2009:241). relations:

There are various benefits that are provided by use of social media as a means of public

- A broad target audience can be reached in a short time,

-There is an opportunity to learn the satisfaction and dissatisfaction of target audience about the product, service or institution in a short time,

- It is easy to inform the target audience about the new developments in products or services,

- It is possible to educate and inform the target audience at a lower cost and in a shorter time (Saran, 2005:65).

Social media can reveal a number of negative consequences as well as positive aspects such as opportunities it presents and its measurability. The fact that negative news can be disseminated very quickly through this media, if the questions, criticisms or compliments of those who have been contacted by social media aren't immediately or very quickly responded, this will result in shaken trust of these people; and in addition to these, infollution, sharing lots of confidential information on forums by employees, and the loss or disclosure of these confidential information can occur; all these can be counted as the drawbacks of social media. (Zafarmand, 2010: 42).

\section{USE OF SOCIAL MEDIA IN HEALTHCARE SECTOR IN TURKEY AND IN THE USA}

When we look at the use of social media by sectors, the healthcare sector undoubtedly falls behind this movement. The rules are not clear in Turkey as it is in the whole world; social media is not being used professionally by our institutions in our country, but it is also an observable fact that the lack of comprehensive research on social media. This section of the work will focus on how the healthcare industry in the United States, where social media is born, draws a profile.

According to the results of a study conducted by the American Medical Association in 2011, 21\% of 5,754 licensed hospitals in the US are actively using social media (Doğanay, 2012 http://sosyalmedya.co/saglik-sosyal-medya-infografik/). This means that one out of every 5 hospitals can promote via Facebook, Twitter, Foursquare or YouTube and communicate with potential or current patients. In social media, $87 \%$ of active hospitals have a Facebook fan page. Immediately following, Foursquare comes with $77 \%$ location based service, where you "check in" to share your location, giving opportunity to see who else is there and comments on previous visits. Next, Twitter is 
followed by about two thirds of these hospitals in order to give information about their future organization, raise the awareness of public and encourage them about the disease screening tests, and to give other useful information to public.

The use of social media by health institutions is not limited to communication with patients and marketing activities. At the same time, these channels are also used for clinical research recruitment, patient monitoring and educational activities.

While $87 \%$ of physicians who participated in this survey indicated that they use social media, a majority $(67 \%)$ that is more than expected stated that they use social media for professional purposes. At this stage, the AMA (American Medical Association) has some suggestions for physicians to separate private and professional profiles in the social media.

What is striking is that $45 \%$ of the health care institutions that have participated in the research and used social media actively have indicated that they do not have a social media policy they have created. This figure is thought to be higher in our country.

\section{METHOD}

After the widespread use of the Internet, social media has begun to be used for public relations purposes, and even institutions, organizations and firms that are delayed in this period are criticized.

The purpose of this study is to investigate the use of social media by the hospitals with the aim of communication and public relations. The universe of this study is hospitals. Mayo Clinic, chosen as the best hospital of 2016 by U.S. News \& World Report, from the USA that is hometown of social media and Medical Park Hospital, taking the first place at the list of the best hospitals determined by Turkish Social Security Institution and at the same time being awarded the first prize in the field of healthcare by Golden Spider Web Prizes were determined as samples for this study.

The websites of Mayo clinic and Medical park and their relevant social media tools have been evaluated through qualitative and quantitative analysis method for a period of four weeks between $1 \mathrm{st}$ and 31st of December, 2016 and throughout the research the following questions about the two organizations were studied:

-To what extend do they use their websites to reflect their corporate identities?

-Are there sponsorships that they carry out in social media and do they have social responsibility studies or not?

-How often do they create contents in social media?

-What are their communication frequencies with the target audience?

-To what extend do they make use of social media?

\section{FINDINGS}

\subsection{Mayo Clinic}

Mayo Clinic is a nonprofit medical practice and medical research group based in Rochester, Minnesota in 1889. It employs more than 4,500 physicians and scientists and 57,100 allied health staff. Mayo Clinic has major campuses in Rochester, Minn.; Scottsdale and Phoenix, Ariz.; and Jacksonville, Fla. The Mayo Clinic Health System has dozens of locations in several states (http://www.mayoclinic.org/about-mayo-clinic).

According to a research conducted by NurseJournal.org, Mayo Clinic is the Best Social Media Friendly Hospitals for 2014 (http://nursejournal.org/articles/top-100-most-social-media-friendlyhospitals-for-2014/).

The Mayo Clinic has long been an online resource for medical information, with a website that offers advice and expertise from more than 3,300 medical professionals for free, so it's not at all surprising that the medical group has been successful in social media. In an interview with Med City News, the Mayo Clinic was named the "poster child for healthcare social media" with social media chief Lee Aase at the helm. The Mayo Clinic has its own social media network where patients can connect, several health promotion campaigns, including "Know Your Numbers," which promotes heart health, and a healthy presence on just about every social media outlet available, including YouTube, Twitter, and Facebook. Even Mayo Clinic doctors are encouraged to take part in social media. The clinic has been so successful in social media, in fact, that they are the hosts of the Health Care Social Media Summit, held in October 2011 with 375 attendees and a buzz reaching about 100 tweets per hour. 


\subsubsection{Web Site}

The most striking factor on the homepage of the site using http://www.mayoclinic.org/about-mayoclinic address is that blue known for its relief, confidence and nobility is used as dominant color. Tabs on the page are in order of "Patient Care \& Health Info, Departments\& Centers, Research, Education, For Medical Professionals, Products \& Services, Giving to Mayo Clinic. In addition to these, on the top right of the page there are links as "Request an Appointment, Find a Doctor, Find a Job, Give Now". These links have made it possible for patients to access the results of their previous analysis and examination. The homepage, which has a rich link facility that offers many options for both patients and visitors, also provides access to a large medical archive containing information on diseases and related treatments. As Mayo Clinic is a not-for-profit organization, someone can donate money under the title of 'Give Now'. There are many links in the rich content of the site, including detailed resumes and achievements of doctors, quality and safety certificates and awards of the hospital, detailed information on ongoing clinical trials and career opportunities for professionals.

There are social media symbols on the right corner of the page that directs the visitors to Twitter, Facebook, Google+, YouTube and Pinterest. The page is full of a broad range of information from billing and insurance to Mayo Clinic School of Medicine. Every single link has detailed information giving the impression that the visitor is at his/her own home. 'Blogs and interactive media' link can be found under the 'Terms and conditions of use policy' title which shows that institution has a professional attitude to use of social media.

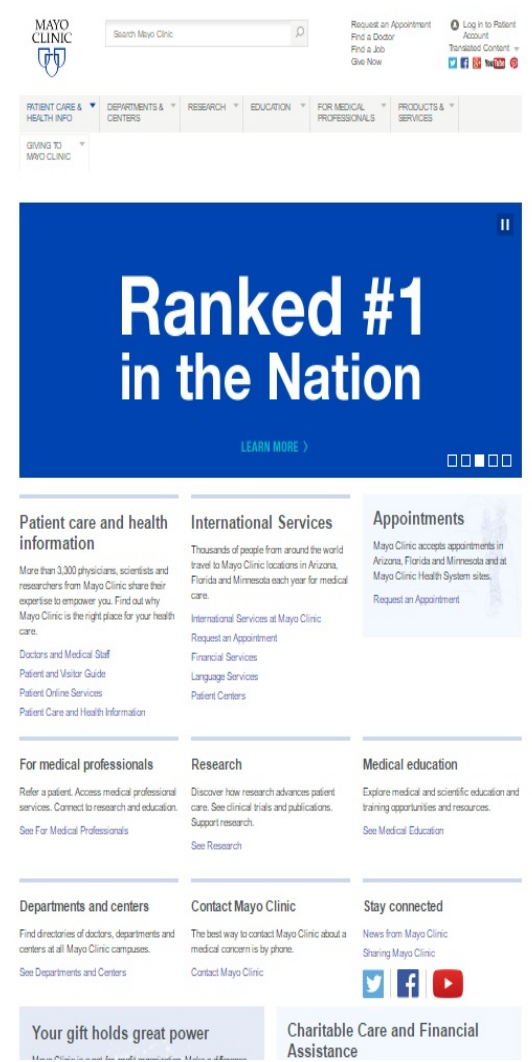

Image 1: Mayo Clinic website page

\subsubsection{Facebook}

Mayo Clinic uses Facebook to communicate with patients, to inform people about organizational activities, to spread campaigns such as organ donation, to alert followers to various diseases, to motivate other patients to treatment by sharing recovery stories of some patients, to remind important days and weeks about health, to share emergency updates of polyclinics (https://www.Facebook.com/MayoClinic).

Table 1: Facebook follower numbers

\begin{tabular}{|l|c|c|}
\hline Mayo Clinic & Like & Follow \\
\hline First week & 908,683 & 877.082 \\
\hline
\end{tabular}


The Turkish Online Journal of Design, Art and Communication - TOJDAC April 2017 Volume 7 Issue 2

\begin{tabular}{|l|c|c|}
\hline Second week & 909.121 & 877.613 \\
\hline Third week & 909.766 & 878.192 \\
\hline Fourth week & 910.548 & 878.989 \\
\hline
\end{tabular}

As it is shown in Table 1, the number of followers of Mayo Clinic showed an average increase during the survey.

On the Facebook page of the institution, sharing is done frequently and not every day, and a visual about this sharing is given. It has been observed that user's questions about shares have been meticulously answered. It is possible to send a message to the institution from the 'Message' section on the page but it has been determined that there is no return to the sent message.

\subsubsection{Twitter}

It has been observed that Mayo Clinic uses Twitter page to communicate with patients, relatives and general followers, to share new developments, to introduce new practices in their own hospitals, the results of their experiments and to announce the latest developments in the treatment of certain diseases.

It was observed that they recommended video and news links to their followers. Compared to Facebook account and Twitter account of the institution, the number of Twitter followers is more than Facebook. It was surprising because of the fact that Twitter is generally less followed.

Table 2 lists the tweets, follow-up and follow-up numbers observed during Mayo Clinic's research. According to the table an average of 15 tweets per day (https://twitter.com/mayoclinic).

Table 2: Mayo Clinic's tweet, followed and follower numbers

\begin{tabular}{|l|c|c|c|}
\hline Mayo Clinic & Tweet & Followed & Follower \\
\hline First week & 176 & 1.801 & 1.420 .211 \\
\hline Second week & 95 & 1.804 & 1.423 .638 \\
\hline Third week & 100 & 1.807 & 1.425 .817 \\
\hline Fourth week & 94 & 1.807 & 1.426 .129 \\
\hline Total number & 465 & & \\
\hline
\end{tabular}

It has been determined that tweets are related to a patient recovery story, some clues for a health life. Tweets to Mayo Clinic are about patients' satisfaction or small problems that need help, but all tweets to institution are positive. The speed of Mayo Clinic's return to these tweets (up to 1 hour) is striking.

\subsubsection{YouTube}

Joining YouTube on June 15, 2006, Mayo Clinic has 48,645 subscribers viewing 30,251,897.Videos are collected under the titles such as 'Pediatrics, 'Mayo Clinic Children's Center, 'Mayo Clinic Minutes', 'Cancer', 'Transplant' etc. It has the possibility to watch all the videos in historical order from the oldest to the newest upload. It was seen that Mayo Clinic published 67 videos during the study. In the discussion section on the page, it is possible to see the comments and questions from followers again. The most watched video is 'Making Mayo's Recipes: Sweet Potato Gnocchi' with 2.277 viewing (https://www.youtube.com/user/mayoclinic/featured).

\subsubsection{Pinterest}

At this point, it will be helpful to first look at what Pinterest is and how it is used and less widely known than Facebook and Twitter. Pinterest is a combination of the words Pin (Needle) and Interest (Interest) and is an application that is considered as Twitter's picture. The biggest difference with Twitter is that it has its own application. This application, called 'Pin it', is used in the browser to use this button to pin the favorite pictures on the sites that are visited later, and to click on the selected images and send them to their own "clipboard".

Mayo Clinic, which has 25,323 followers and 189 follow-ups on Pinterest account, pinned 1643 pictures using 29 Board (board). The photos are about healthy life, Mayo Clinic employees and campus, Mayo Clinic teams and activities, operations, pregnancy, fitness facts, good eats, healthy snacks, healthy habits, cancer care, cardiology, diabetes, meditation,Mayo Clinic books, fitness injuries and yoga (https://tr.pinterest.com/mayoclinic/).

\subsubsection{Flickr}

Flickr describes itself as almost certainly the best online photo management and sharing application in the world. It is stated on its page that it has two main goals: 
-to help people make their photos available to the people who matter to them.

-to enable new ways of organizing photos and video (https://www.flickr.com/about).

3.1.7. Foursquare

Mayo Clinic joined to Flickr in 2008 has 2000 followers and 8859 photos on its page.

Mayo Clinic has 3,556 followers on Foursquare, an application based on your location reporting and social networking (https://tr.foursquare.com/mayoclinic?all=followers).

\subsubsection{LinkedIn}

LinkedIn, a social networking site, was developed for professionals. It was established in December 2002 but went into use in May 2003. It is mainly used for professional networks. According to LinkedIn reports in February 2012, more than 150 million users are in more than 200 countries (Http://en.wikipedia.org/wiki/Linkedin).

Widely used in many countries of the world, LinkedIn is the world's largest professional network on the Internet (http://pres.linkedin.com/about). LinkedIn provides real and effective communication network and network development opportunities to all the professionals. Within this social network, business environment can be improved and potential new business connections can be established (Güçdemir, 2012:47).

Mayo Clinic has also benefited from LinkedIn to recruit qualified staff for vacancies like many other companies and companies. It has also been found that the recruited persons share the page (https://www.linkedin.com/company/mayo-clinic).

\subsubsection{RSS}

It was identified that by subscribing to the MayoClinic.org RSS feeds, someone can identify the types of content he /she is most interested in and receive an alert when new and updated topics are published.

(http://www.mayoclinic.org/about-this-site/rss-feeds)

\subsubsection{Blogs}

It was seen that Mayo Clinic had five blogs called as News Blog, Podcast Blog, Advancing the Science Blog, Health Blogs and Nurse Recruitment Blog. It was determined that these blogs were used actively and effectively by sharing at least four or five subjects almost every day. Subjects diversify from cancer to healthy diet (http://newsnetwork.mayoclinic.org/).

\subsection{Medical Park}

Medical Park Hospitals Group, which has been active in the field of hospitals in Turkey since 1993, provides service in various provinces of Turkey with 22 hospitals, and 1 medical center, a total of 23 service centers and more than 12,900 employees.

Medical Park, which carries international standards in hospitality with the philosophy of "Health for All" to every socioeconomic status profile throughout Turkey, aims to be an example for the world health sector with its new applications supporting science as well as following advanced technology and treatment methods in the world.

The Medical Park Hospitals Group, combining experts in the field, superior patient-focused service approach and multidisciplinary work, offers quality diagnostic and treatment services with its 4 accredited hospitals by American Joint Commission International (JCI) (http://www.Medical Park.com.tr/hakkimizda).

The Digital Asset Rating, which was first implemented in Turkey, determined the top 100 brands among the leading companies of our country. The SocialMark 100, where the leading brands of social networks took social media accounts into consideration, ranked Medical Park Hospitals Group 13th. Medical Park Hospitals Group was also on the first rank among the listed hospitals.

\subsubsection{Web Site}

Similar to the Mayo Clinic, the entrance page of the Medical Park Hospital web site has been observed to be dominated by blue tones and a design for giving visitors a sense of calm, confidence and quality. The main links that are highlighted on the scene at the first sight are seen as "hospitals, physicians, online services, contracted institutions, health information and medical departments". The "appointment" link immediately above it, which is written in red, is highlighted with larger type sizes as a service link that allows the patient to make an appointment over the internet. Right in the middle of the main page, there is a zone in the form of a belt, which is designed to cover about half of the site, 
moving and changing, with news and photos of the campaigns as big pictures and photographs. Below these, there is a "hospitals" link and small pictures of the branches. Below this again, there are links such as "patient and sight" link, as well as links to health information, institutional, online services, media and communication that are arranged side by side and are written in transparent gray medium size type sizes and have sub links to inform patients and their relatives. There are sublinks of the health information link such as the health corner, the health guide, and a "medical follow-up center" link where patients can access the results of their own investigations and outcomes, as well as reminders about future controls.

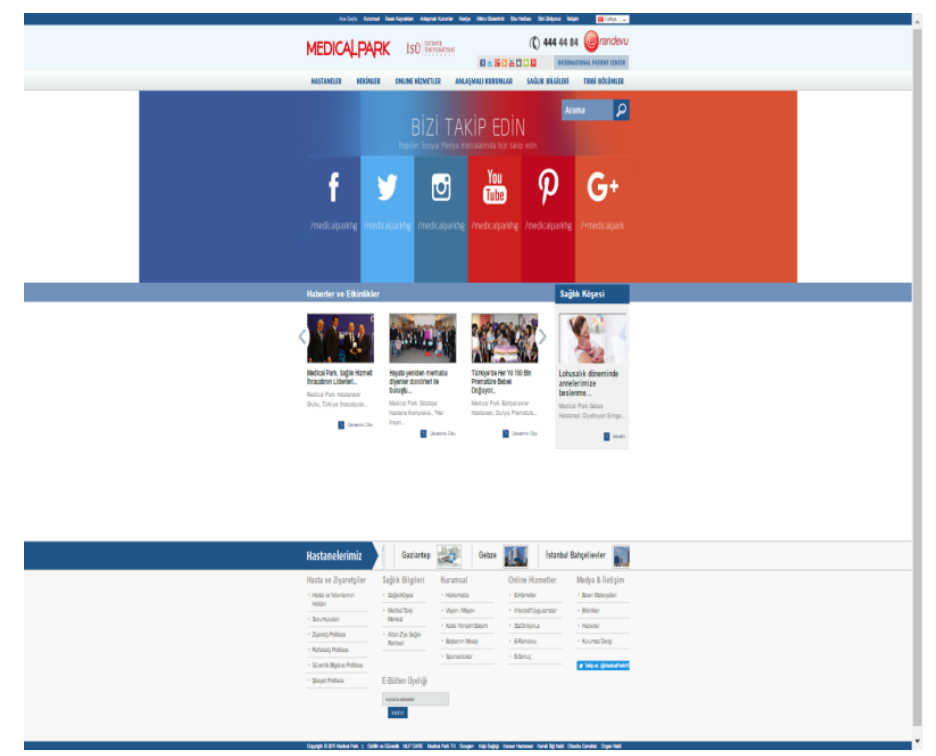

Image 2: Medical Park Website Page

\subsubsection{Facebook}

The Medical Park hospital has a Facebook page that last week, 180,406 people liked, 4423 people talked about and 2,000 people visited on average a day (https://www.Facebook.com/Medical ParkHG/).

Table 3: Facebook like and follower numbers

\begin{tabular}{|l|c|c|}
\hline $\begin{array}{l}\text { Medical Park } \\
\text { Hospital }\end{array}$ & Like & Follower \\
\hline First week & 179.254 & 176.903 \\
\hline Second week & 179.621 & 177.078 \\
\hline Third week & 180.024 & 177.142 \\
\hline Fourth week & 180.406 & 177.237 \\
\hline
\end{tabular}

Using the Facebook page for making announcements and promotions related to the hospital, sharing the latest developments in the field of medicine, sharing the successful operations that the hospital has done, directing to the daily life about health and nutrition recommendations, and sharing the opinions of hospital doctors on 'Uzman TV' and 'YouTube' Medical Park, which uses it to direct video content containing medical explanations, allows sending messages via its page but messages are answered by a bot not a human. The comments made on the page were positive and no negative comments were found during the observation period.

The Facebook page of the institution is updated not every day but frequently, and a visual about this update is included. It was determined that some questions of patients about their health problems were also answered and patients were directed to related department of institution with a link. The number 
of people who followed and spoke about the institution showed a significant increase over the observed period

\subsubsection{Twitter}

Participating in twitter 'in 2009 Medical Park, like the Mayo Clinic, has been identified as using the twitter page to communicate with patients, relatives and general followers, to share new developments and to announce new practices in their own hospitals. Tweets especially focus on winter diseases, signs, treatments and measures to be taken against these diseases. Winter depression, pharyngitis, cough, rhythm disturbance are some of these diseases. In addition to these, some announcements were shared about live meetings on Facebook with doctors. The hospital, which determines the users not tweeting directly to the hospital but publishes tweets about their health problems on their own pages sends tweets to the users and directs them to the health branch or department related to the subject on their internet sites. Compared to Facebook account and Twitter account of the institution, the number of Twitter followers is less than Facebook. This is thought to be due to Twitter being generally less followed.

Table 4 shows the number of tweets, followers, and followed observed during Medical Park's research. During the research period, the institution was determined to throw 42 tweets. This number makes the impression that Medical Park is not very active in this period on Twitter. (https://twitter.com/Medical Parkhg)

Table 4: Medical Park tweet, follower and followed numbers

\begin{tabular}{|l|l|l|l|}
\hline $\begin{array}{l}\text { Medical Park } \\
\text { Hospital }\end{array}$ & Tweet & Follower & Followed \\
\hline First week & 12 & 11.755 & 15 \\
\hline Second week & 10 & 11.798 & 15 \\
\hline Third week & 8 & 11.803 & 15 \\
\hline Fourth week in & 12 & 11.814 & 15 \\
\hline $\begin{array}{l}\text { Total } \\
\text { December }\end{array}$ & 42 & \\
\hline Total on Page & 22.340 & & \\
\hline
\end{tabular}

\subsubsection{Youtube}

Medical Park, which joined YouTube on 3 July 2011, has 2923 subscribers and 2,913,968 views. It has the possibility to watch all the videos in historical order from the oldest to the newest uploads. There is no comment in the discussion section on the page. Also it was seen that Medical Park hadn't published any video since 22 November 2016. The most watched video is, "Keeping Live by Organ Donation Is in Your Hand!" Video with 131,227 views (https://www.youtube.com/user/Medical Parkhg).

\subsubsection{Pinterest}

Medical Park, which has 152 followers and 40 followers on Pinterest account, has pinned 803 pictures using 11 Board (board). Photographs are gathered under the headings such as health for all, events, special days, sports health, information posters, no to obesity. (https://pinterest.com/Medical Parkhg/)

\subsubsection{Flickr}

Medical Park hasn't got a Flickr account.

\subsubsection{Foursquare}

On the Foursquare page, Medical Park has 833 followers (https://tr.foursquare.com/Medical Parkhg).

\subsubsection{LinkedIn}

It was observed that Medical Park uses LinkedIn is to get qualified staff for vacant positions. It was determined that the recruited persons and the persons who have raised positions within the organization are also shared on the page. In addition, the institution uses LinkedIn to provide information about its campaigns (https://tr.linkedin.com/in/Medical Parkhg).

\subsubsection{RSS}


The Turkish Online Journal of Design, Art and Communication - TOJDAC April 2017 Volume 7 Issue 2

Patients, relatives and general followers have also been able to use the RSS application to make it easier to access new news, content and updates about Medical Park. (http://feeds.feedburner.com/Medical ParkHG)

\subsubsection{Blogs}

There is no official block of the Medical Park hospital group itself.

\section{THE EVALUATION OF THE USE OF SOCIAL MEDIA BY MAYO CLINIC AND MEDICAL PARK HOSPITALS IN TERMS OF PUBLIC RELATIONS}

- From the point of view of the web pages, the website of the two hospitals has a site interface that provides a similarly designed functional and accessibility, access to a lot of information and appointments on the internet, and control of the analysis and examination results. Terms and Conditions link about use of social media on Mayo Clinic website isn't available on Medical Park; suggesting that Mayo Clinic is more professional in using social media.

- When both Facebook and twitter are evaluated, both sites have their addresses and activities on these social media sites. Mayo Clinic seems to be more active on both Facebook and twitter accounts. Again, from a content point of view, Mayo Clinic uses these social networking sites for informational purposes rather than advertisements, including scientific research results and doctor's opinions. Medical Park, in particular, uses the twitter account to provide information on more popular and shallow topics.

- Both institutions have their own channels on YouTube. Mayo Clinic has numerical superiority in content and number of audiences. While Medical Park shares contents about diseases, Mayo Clinic shares videos daily and has a much richer share of content. The surprise of Medical Park's last sharing is very old can be seen as a sign that this area is not used very actively and effectively by Medical Park.

- Both institutions are involved in the Pinterest practice. However, Mayo Clinic has a numerical advantage. Although Medical Park hasn't a Flickr account, Mayo Clinic has. This can be interpreted as Mayo Clinic's holistic approach to social media and its manifestation in almost all popular social media circles.

- Both institutions are involved in Foursquare application, but in terms of number of visitors, Mayo Clinic has numerical superiority.

- In the implementation of LinkedIn both institutions have accounts. For purposes of use, Mayo Clinic seems to be more focused on recruitment and recruitment activities; Medical Park uses the site to promote campaigns and promotions with less attention to occupation.

- While Mayo Clinic has five blogs, Medical Park doesn't have a blog.

- Both sites support the use of RRS.

\section{RESULT}

The social media platform has become one of the musts for organizations to be competitive within today's marketing and promotional trends and to be able to create brand image globally. Being in an internet-based communication environment that removes the hierarchy between individuals and the borders between countries has become a necessity for institutions operating in the health sector like all other institutions. As a result of research it is clear that social media awareness in hospitals is growing, as well as its use. However, these hospitals don't actively engage online with consumers on Facebook pages. This lack of engagement can be evaluated as a loss of opportunity to enhance customer service, improve quality of care, and build loyalty. Another result is the fact that social media usage differs significantly between countries. In addition to this, although both of the hospitals adopt at least one social media platform, their activity level varies depending on the platform.

Within the framework of these dynamics, it is among the results of this research that USA-based health institutions use social media in a more professional and relevant way. In fact, both institutions compared in the research are actively using social media over international social media sites, which are also popular in their home country.

Finally, Figure 1 presents Health Social Networking thematic web showing the relationships between the identified theme purpose groups, categories, and subcategories. 


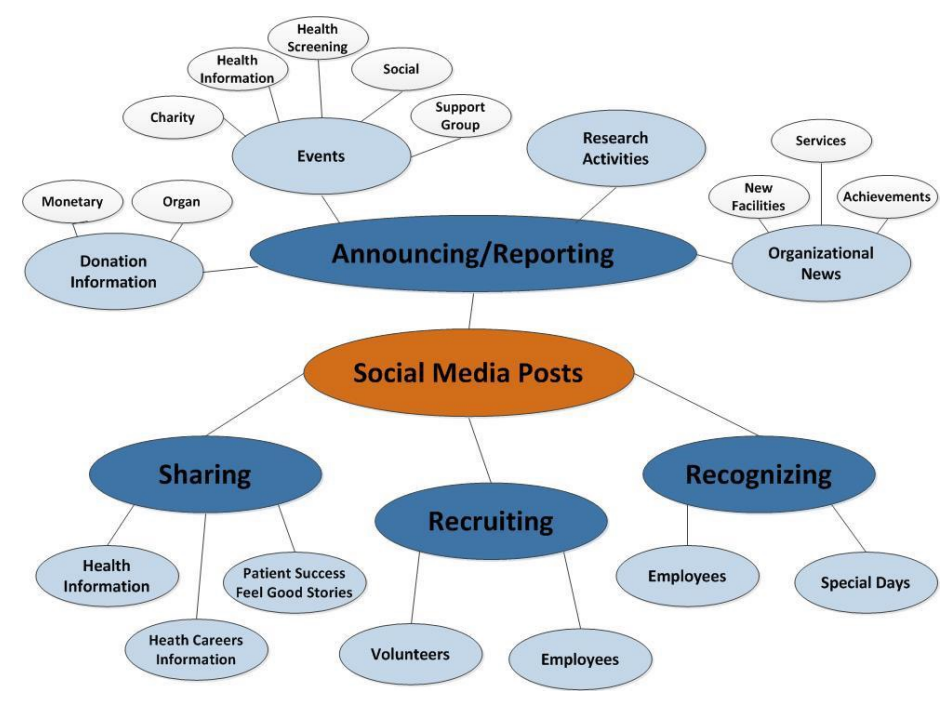

Figure 1: Health Social Media Thematic Web

\section{REFERENCES}

Canöz, K. (2010) Sağllk Kuruluşlarında Halkla İlişkiler Uygulamaları, Palet Yayınları,Konya.

Demetrlou, G. (2011) Organisational Social Media Platforms: Exploring User Participation Behaviours in Software and Technology Firms, A thesis submitted to The University of Manchester for the degree of Doctor of Philosophy in the Faculty of Humanitie, Manchester Business School, England.

Güçdemir, Y. (2012) Sanal Ortamda İletişim: Bir Halkla İlişkiler Perspektifi, Derin Yayınları, Istanbul.

Griffis, Heather M.and the others (2014) Use of Social Media Across US Hospitals: Descriptive Analysis of Adoption and Utilization, Vol.16, No 11

Gunelius, S. (2011), 30 minute Social Media Marketing: Step by Step Techniques to Spread the Words about your Business, McGraw-Hill: USA.

Horton, James L. (2009) PR and Social Media - http://www.onlinepr.com/Holding/PR_and_Social_media.pdf

Safko, L. (2010). The Social Media Bible. New Jersey: John Wiley and Sons.

Kaplan, A. M., and Haenlein, M. (2010). Users of the world, unite! The challenges and opportunities of Social Media. Business Horizons (53), 59-68.

Kordzadeh, Nima and Young, Diana K. (2015) Understanding How Hospitals Use Social Media: An Exploratory Study of Facebook Posts, Twenty-first Americas Conference on Information Systems, Puerto Rico.

Maifredi G., Orizio G. et al. (2010), "Italian hospitals on the web: a cross-sectional analysis of official websites" // BMC Medical Informatics and Decision Making (published online). -2010. - Vol. 10:17. - http://www.biomedcentral.com/1472-6947/10/17.

Onat, F. (2009) Bir Halkla İlişkiler Uygulama Alanı Olarak Sosyal Medya: Sivil Toplum Örgütleri Üzerine Bir Inceleme, Ankara, Gazi Üniversitesi ĠletiĢim Dergisi, Sayl: 7/2, s. 241.

Saran, M. (2005) Internet ve Halkla İlişkiler, İstanbul, Yeni Düşünceler, Sayl:1/1, s. 65.

Seiple, Pamela , How to Leverage Social Media for Public Relations Success http://cdn2.hubspot.net/hub/53/file-13204195-pdf/docs/hubspot_social_media_pr_ebook.pdf

Thaker ve Edwards (2010), How U.S. Hospitals Use Social Media, Annals of Internal Medicine Volume 154・Number 10, www.annals.org., 02.01.2017 
The Turkish Online Journal of Design, Art and Communication - TOJDAC April 2017 Volume 7 Issue 2

Zafarmand, N. (2010) Halkla İlişkiler Alanında Yeni Mecra Ve Uygulamaların Yeri Ve Önemi: Sosyal Medya Ve Pr 2.0, Gazi Üniversitesi, Sosyal Bilimler Enstitüsü, Halkla İlişkiler Ve Tanıtım Anabilim Dall, Yüksek Lisans Tezi, Ankara.

Doğanay, (2012) Săğlk Sektörü Sosyal Medyayı Nasıl Kullaniyor? http://sosyalmedya.co/sagliksosyal-medya-infografik/

http://www.mayoclinic.org/about-mayo-clinic

https://www.Facebook.com/MayoClinic

https://twitter.com/MayoClinic

https://tr.pinterest.com/mayoclinic/

http://www.Medical Park.com.tr/

https://www.Facebook.com/Medical ParkHG/

https://twitter.com/Medical Parkhg

https://www.pinterest.com/Medical Parkhg/ 